Review

\title{
Lung Cancer Management with Silibinin: A Historical and Translational Perspective
}

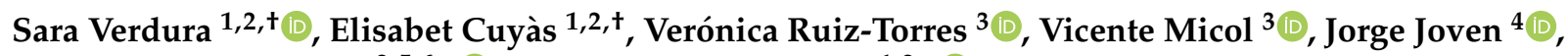 \\ Joaquim Bosch-Barrera 2,5,6,*(D) and Javier A. Menendez ${ }^{1,2, *(D)}$ \\ 1 Girona Biomedical Research Institute (IDIBGI), 17190 Girona, Spain; sverdura@idibgi.org (S.V.); \\ ecuyas@idibgi.org (E.C.) \\ 2 Metabolism and Cancer Group, Program against Cancer Therapeutic Resistance (ProCURE), \\ Catalan Institute of Oncology, 17007 Girona, Spain \\ 3 Instituto de Investigación, Desarrollo e Innovación en Biotecnología Sanitaria de Elche (IDiBE) and Instituto \\ de Biología Molecular y Celular (IBMC), Universidad Miguel Hernández (UMH), 03202 Elche, Spain; \\ vruiz@umh.es (V.R.-T.); vmicol@umh.es (V.M.) \\ 4 Unitat de Recerca Biomèdica (URB-CRB), Hospital Universitari de Sant Joan, Institut d'Investigació Sanitària \\ Pere Virgili, Universitat Rovira i Virgili, 43201 Reus, Spain; jjoven@grupsagessa.com \\ 5 Medical Oncology, Catalan Institute of Oncology, Dr. Josep Trueta Hospital of Girona, 17007 Girona, Spain \\ 6 Department of Medical Sciences, Faculty of Medicine, University of Girona (UdG), 17003 Girona, Spain \\ * Correspondence: jbosch@iconcologia.net (J.B.-B.); jmenendez@idibgi.org (J.A.M.) \\ + Both authors contributed equally to this work.
}

Citation: Verdura, S.; Cuyàs, E.; Ruiz-Torres, V.; Micol, V.; Joven, J.; Bosch-Barrera, J.; Menendez, J.A. Lung Cancer Management with Silibinin: A Historical and Translational Perspective. Pharmaceuticals 2021, 14, 559. https:// doi.org/10.3390/ph14060559

Academic Editor: Thomas Efferth

Received: 12 May 2021

Accepted: 9 June 2021

Published: 11 June 2021

Publisher's Note: MDPI stays neutral with regard to jurisdictional claims in published maps and institutional affiliations.

Copyright: (C) 2021 by the authors. Licensee MDPI, Basel, Switzerland. This article is an open access article distributed under the terms and conditions of the Creative Commons Attribution (CC BY) license (https:// creativecommons.org/licenses/by/ $4.0 /)$.

\begin{abstract}
The flavonolignan silibinin, the major bioactive component of the silymarin extract of Silybum marianum (milk thistle) seeds, is gaining traction as a novel anti-cancer therapeutic. Here, we review the historical developments that have laid the groundwork for the evaluation of silibinin as a chemopreventive and therapeutic agent in human lung cancer, including translational insights into its mechanism of action to control the aggressive behavior of lung carcinoma subtypes prone to metastasis. First, we summarize the evidence from chemically induced primary lung tumors supporting a role for silibinin in lung cancer prevention. Second, we reassess the preclinical and clinical evidence on the effectiveness of silibinin against drug resistance and brain metastasis traits of lung carcinomas. Third, we revisit the transcription factor STAT3 as a central tumor-cell intrinsic and microenvironmental target of silibinin in primary lung tumors and brain metastasis. Finally, by unraveling the selective vulnerability of silibinin-treated tumor cells to drugs using CRISPR-based chemosensitivity screenings (e.g., the hexosamine biosynthesis pathway inhibitor azaserine), we illustrate how the therapeutic use of silibinin against targetable weaknesses might be capitalized in specific lung cancer subtypes (e.g., KRAS/STK11 co-mutant tumors). Forthcoming studies should take up the challenge of developing silibinin and/or next-generation silibinin derivatives as novel lung cancer-preventive and therapeutic biomolecules.
\end{abstract}

Keywords: silibinin; silymarin; non-small cell lung cancer; EMT; metastasis; STAT3

\section{Introduction}

Phytochemicals are biologically active compounds synthesized by plants (Phyto means "plant" in Greek). The term, however, is generally employed for those influencing human health. Flavonoids are a subclass of polyphenol phytochemicals that are commonly present in fruits, vegetables, nuts, seeds, herbs, spices, stems, flowers, teas, and red wine [1,2]. As they have existed in nature for millions of years, flavonoids have a long historical association with animal species throughout evolution, which likely explains their myriad biochemical and pharmacological properties [3]. Although not without limitations, the mutualistic relationship between plant flavonoids and animals, which is embraced in the concept of xenohormesis [4,5], can be applied to human pathophysiology; in particular, the 
various bioactivities of flavonoids (e.g., anti-inflammatory, antioxidant, antiallergic, hepatoprotective, antithrombotic, antiviral, and anticarcinogenic) in numerous biological systems.

Flavonolignans are a minor subclass of flavonoids comprising a flavonoid moiety and a lignan (phenylpropanoid) part. They were first isolated from the seeds of milk thistle (Silybum marianum (L.) Gaertn.), an annual/biannual plant of the Asteraceae family flowering in July-August with characteristic reddish-purple flowers. The milk thistle is indigenous to South Europe, South Russia, Asia Minor, and North Africa, but has also been naturalized in North and South America and in South Australia. The so-called silymarin extract of milk thistle, which was classified by the World Health Organization as an official medicine with health-promoting properties in the 1970s, is obtained through organic solvent extraction and represents $1.5-3 \%$ of the dry weight of the fruit. Silymarin contains a mixture of flavonolignans of mainly four isomers: silibinin (or silybin), isosilybin, silychristin, and silydianin. There is also a minor fraction of polymeric and oxidized polyphenolic components [6-12], including two pairs of diastereomers-silibinin A/B and isosilybin A/B. Silibinin is composed of a 1:1 mixture of silibinin A and B and comprises $50-70 \%$ of the extract and $20-40 \%$ of the commonly used pharmaceutical preparations $[11,13,14]$. Whereas the chemical composition of milk thistle fruits includes other flavonoids (e.g., taxifolin, quercetin, kaempferol, apigenin), the highest concentration of silymarin corresponds to silibinin, which is considered the major bioactive component [15-18].

Originally described as a cure for the venom of poisonous snakes, silibinin is the most extensively studied flavonolignan and is currently clinically employed to treat amatoxin/Amanita mushroom poisoning or lipotoxic injury in fatty liver diseases. Here, we review the historical context of the development of silibinin research in lung cancer (Figure 1). A literature search (silibinin AND lung cancer) was initially conducted in the electronic database PubMed with no date-range restriction. No quality-assessment scale systems were used to evaluate the collected studies. Manuscripts were screened by checking the title and abstract or reading the full text to determine their inclusion. In addition, we provide some experimental results to illustrate how we might capitalize on the therapeutic use of silibinin against targetable weaknesses in specific subgroups of patients with lung cancer.

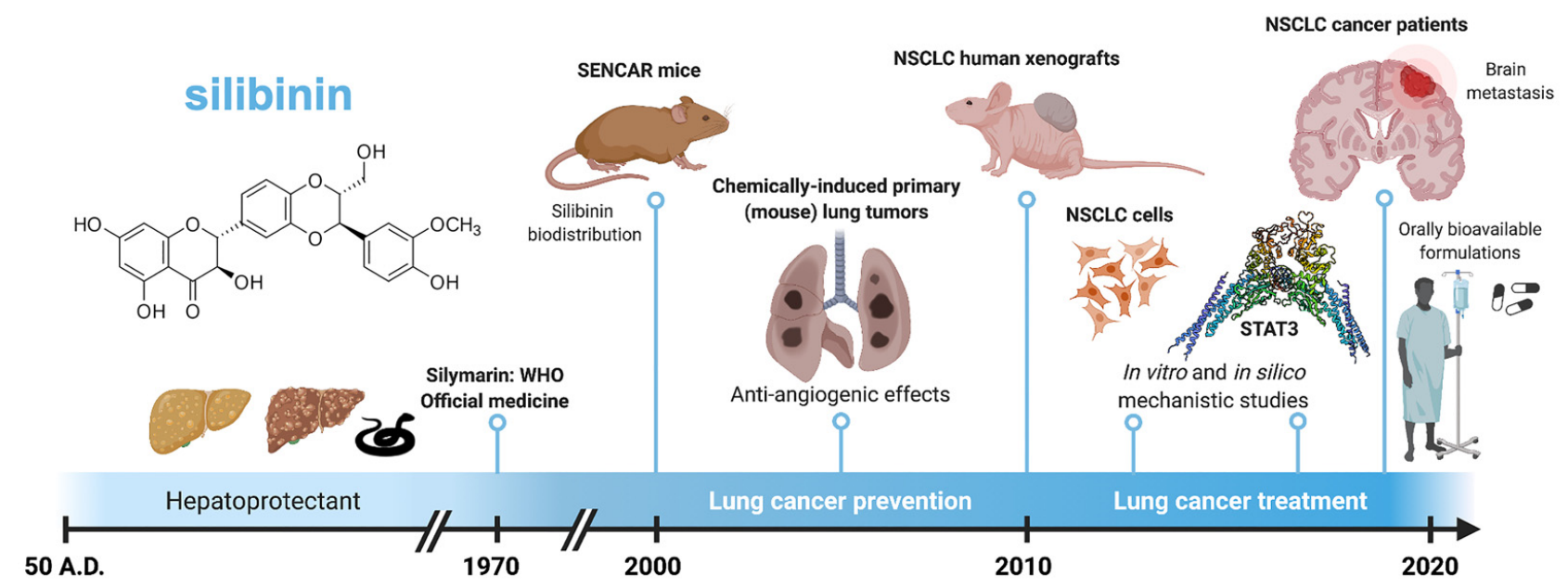

Figure 1. Key milestones in the timeline of silibinin research in lung cancer. Originally employed as a hepatoprotectant and a remedy for the bites of poisonous snakes hundreds of years ago, silibinin has recently demonstrated significant clinical activity in patients with non-small cell lung cancer and brain metastases when used in new orally bioavailable formulations. Created with BioRender. 


\section{Silibinin-Containing Milk Thistle Fruits and Human Health: A Brief Historical Overview}

The name milk thistle originates from a legend that Mary, when leaving for Egypt with the infant Jesus, found shelter in a bower formed from the thorny leaves of S. marianum. While nursing Jesus, she spilled some breast milk onto the plant, and this resulted in the characteristic milky-white veins of the plant's leaves.

Milk thistle fruits have been used for over 2000 years in the treatment of liver- and biliary-related diseases. While the first record of $S$. marianum can be found in the Old Testament (Genesis 3:18), it had already been used in ancient Greece and in millenarian Indian and Chinese medicines to resolve liver and gallbladder problems. Theophrastus of Eresos (fourth century B.C.), Pedanios Dioscorides (50 A.D.), and Plinius the Elder (first century A.D.) were the first to report the medicinal benefits of milk thistle fruits. In his work "De Materia Medica", Dioscorides described S. marianum as a remedy for the bites of poisonous snakes and for melancholic depression, which was believed to be a "liver complaint" at that time.

Used in the Middle Ages as an antidote for liver toxins, renaissance and humanistic naturalists and physicians included milk thistle in their herbal medicine armamentarium. Native American Indians, 19th century physicians, and herbalists also employed preparations of milk thistle fruits to treat a variety of diseases, particularly liver pathologies. In the last 40-50 years, the use of silibinin-dependent, bioactive silymarin extracts for treatment of liver disorders such as alcoholic liver disease, nonalcoholic liver disease, drug-induced liver injury, cirrhosis, viral hepatitis, and mushroom poisoning has been well documented $[12,18,19]$. Patients with liver disorders treated with silymarin show a more rapid improvement in liver function than those receiving placebo. Likewise, in patients with alcoholic liver cirrhosis, administration of silymarin for several years resulted in a significantly reduced mortality rate $[15,20]$. Not surprisingly, silymarin is one of the most frequently sold dietary supplements for hepatitis and cirrhosis in the USA and Europe [21].

\section{Silibinin to Therapeutically Manage Lung Cancer: Pioneering Studies}

Dr. Agarwal and colleagues at the University of Colorado Health Sciences Center (Denver, USA) pioneered the investigation of silibinin to prevent and treat human malignancies in different experimental models of skin [22,23], prostate [24,25], and lung [26,27] cancer. Based on the strong antioxidant activity of silymarin and the fact that it was already in clinical use for a range of liver, gall bladder, and even dermatological conditions [28], they conducted a series of cancer-centered studies with silymarin in both short-term cell culture and long-term animal models. Using SENCAR mice, which are highly sensitive to tumor initiation and promotion in response to carcinogens and promoters [29,30], they initially assessed the tissue biodistribution and conjugate formation of systematically administered silibinin in different mouse tissues and its effect on phase II detoxification enzymes [26]. They found that silibinin could rapidly distribute as both free and conjugated forms and significantly induced phase II enzymes in the tissues examined. These findings strongly suggested that silibinin might reach target organs to exert anti-cancer effects, providing the first basis to evaluate the cancer preventive and interventive effects of silibinin in experimental models of carcinogenesis [26]. Using established cell models of small cell (SCLC) and non-small cell (NSCLC) lung carcinoma, the Agarwal group was the first to report that micromolar concentrations of silibinin could significantly increase growth inhibition, cell cycle arrest, and apoptotic cell death [31], warranting further studies to establish the efficacy and mechanism(s) of action of silibinin as a non-toxic therapeutic agent in additional lung tumor models.

\section{Silibinin and Lung Cancer Prevention: Evidence from Chemically Induced Primary Lung Tumors}

The Agarwal group demonstrated that oral silibinin ( $200 \mathrm{mg} / \mathrm{kg}, 5 \mathrm{~d} / \mathrm{wk}$ for 33 days) inhibited NSCLC A549 xenograft tumor growth and suppressed the systemic toxicity of 
co-administered doxorubicin in athymic BALB/c nu/nu mice through a mechanism likely dependent on the regulation of nuclear factor kappaB $(\mathrm{NF} K \mathrm{~B})$, a key player in the chemoresistance and dose-related (acute and cumulative) toxicity of anthracyclines [32]. In contrast to these findings, Yan and colleagues reported the failure of $0.05 \%$ and $0.1 \%$ silibinin in the diet $(w t / w t)$ to significantly reduce tumor multiplicity and load in a mouse model of tobacco-driven lung carcinogenesis [33]. In another study by the Agarwal group, the lack of efficacy of silibinin in preventing benzo(a)pyrene-induced pulmonary adenoma formation and growth reported in the aforementioned Yan study was not observed when the effects of dietary silibinin $(0-1 \% w t / w t)$ on the growth, progression, and angiogenesis of lung tumors induced by urethane (a carcinogenic contaminant of alcoholic beverages and other fermentation products) were tested in A/J mice [34]. Chronic oral consumption of silibinin significantly lowered lung tumor multiplicity, prevented lung tumors from growing beyond a small size (in a dose-dependent fashion), and blunted tumor angiogenesis, a plausible mechanism contributing to the efficacy of silibinin in this model [34].

Mechanistically, the cancer-preventive activity of silibinin was initially attributed to the reduced lung tumor expression of the angiogenic factor vascular endothelial growth factor (VEGF), mediated by the suppression of VEGF regulators such as cyclooxygenase-2 (COX2) and inducible nitric oxide synthase (iNOS) [34]. Silibinin appeared to target multiple cytokine (IFN $\gamma, \mathrm{IL}-1 \beta$, and TNF- $\alpha$ )-induced signaling pathways such as the signal transducer and activator of transcription 3 (STAT3) to ultimately lower COX2 and iNOS expression in lung cancer cells $[35,36]$. When the chemotherapeutic effects of oral silibinin on the growth and progression of established, urethane-induced, lung adenocarcinomas in $\mathrm{A} / \mathrm{J}$ mice were studied, its strong ability to suppress both tumor number and size correlated with a reduced antiangiogenic activity mediated by decreased cytokine production in tumor-associated macrophages and suppression of NFKB and STAT3 activation in lung cancer cells [36]. Importantly, the capacity of silibinin to prevent urethane-induced lung tumorigenesis in mice was completely lost upon genetic ablation of Nos2 (iNOS) [37], strongly suggesting that silibinin exerts its chemopreventive and angiopreventive effects through blockade of iNOS expression in lung tumors. Careful examination of the mechanism of action of silibinin on cell signaling elicited by a cytokine mixture (IFN $\gamma+$ TNF- $\alpha$ ) in tumor-derived LM2 mouse lung epithelial cells revealed that its ability to regulate the expression of metalloproteinases and the angiogenesis drivers COX2 and iNOS was causally mediated through impairment of STAT3 activation and nuclear localization [38]. As no $50 \%$ lethal dose $\left(\mathrm{LD}_{50}\right)$ has been reported in laboratory animals, and silibinin treatment has been considered exceptionally safe after acute or long-term chronic administration in both animals and humans, these findings strongly supported the investigation of silibinin as a chemopreventive agent for suppressing lung tumor growth and progression in humans [27].

\section{Silibinin and Lung Cancer Treatment: Evidence from Laboratory In Vitro and Animal Models}

An ever-growing number of studies have tested the capacity of silibinin to exert inhibitory activities against cultured cancer cells and tumor xenografts, to enhance the efficacy of other therapeutic agents (reviewed in [39,40]), and to block the emergence of cancer drug resistance in pre-clinical models of lung cancer, including those involving NSCLC-targeted therapies such as epidermal growth factor receptor (EGFR)- and anaplastic lymphoma kinase (ALK)-tyrosine kinase inhibitors (TKIs).

\subsection{Silibinin and Lung Cancer Drug Resistance}

Early studies evaluating silibinin against established cell lines representative of different NSCLC subtypes revealed that micromolar concentrations significantly inhibited cell proliferation by inducing cell cycle arrest and modulating multiple cell cycle regulators, including cyclin-dependent kinases and their corresponding cyclins [41,42]. In later studies, we and others described the capacity of silibinin to exert cytostatic, cytotoxic, and apoptotic effects in various 
NSCLC cell models [43-45]. Importantly, silibinin could restore drug sensitivity to NSCLC cells with acquired resistance to EGFR- and ALK-TKIs in vitro and in vivo.

Rho and colleagues investigated whether the addition of silibinin to EGFR-targeted therapy using first-generation EGFR-TKIs (gefitinib or erlotinib) could overcome primary and acquired resistance due to the presence of the EGFR T790M mutation [46]. They found that silibinin enhanced the ability of EGFR-TKIs to downregulate EGFR signals by inhibiting receptor dimerization of EGFR family members (EGFR, HER2, and HER3) in vitro. Moreover, the combination silibinin and erlotinib suppressed tumor growth in erlotinib-resistant (EGFR T790M) PC-9 NSCLC xenografts [46]. The ability of silibinin to resensitize NSCLC cells to EGFR- and ALK-TKIs occurs even in the absence of secondary EGFR mutations. Using gefitinib- and erlotinib-refractory NSCLC cell models in which EGFR-TKI resistance occurs via the activation of bypass survival signals with other receptor tyrosine kinases (e.g., hyperactive insulin-like growth factor-1 receptor [IGF-1R]) [47] and/or epithelial-to-mesenchymal transition (EMT) [48,49], a water-soluble form of silibinin complexed with the amino-sugar meglumine could efficiently restore EGFR-TKI sensitivity in NSCLC mouse xenografts $[48,49]$. Mechanistically, silibinin could differentially eliminate cancer stem cell (CSC)-like cells within EGFR-TKI-refractory heterogeneous NSCLC populations with aldehyde dehydrogenase isoform 1 (ALDHA1) overexpression and self-renewal capacity [43,50]. Using a model of ALK-translocated NSCLC in which acquired refractoriness to the ALK-TKI crizotinib was driven by activation of TGF $\beta$-induced EMT in the absence of secondary mutations in the kinase domain of ALK, silibinin-induced inhibition of STAT3 was found to synergistically interact with crizotinib to reverse acquired resistance and restore sensitivity in crizotinib-resistant cells [46].

Although scarce, new studies are beginning to shed light on the ability of silibinin to reverse the multidrug resistance (MDR) phenotype of lung cancer cells. Silibinin has been shown to act synergistically with some chemotherapeutics (e.g., doxorubicin, etoposide) in multidrug-resistant SCLC cells through a mechanism that might involve the direct inhibition of adenosine triphosphate binding cassette (ABC)-transporters such as human P-glycoprotein and multidrug resistance-associated protein-1, as well as the downregulation of the expression of the respective $A B C B 1$ and $A B C C 1$ genes [51-56]. Because most patients with advanced EGFR- or ALK-positive NSCLC will receive chemotherapy at some point during their treatment course, it would seem desirable to evaluate whether silibinin specifically impacts EGFR mutation- and ALK translocation-driven chemosensitivity profiles. Using the CRISPR/Cas9-edited EML4-ALK fusion isogenic model in A549 NSCLC cells, which naturally harbor other genomic aberrations inherent in NSCLC (e.g., KRAS/STK11 co-mutation), we recently performed a chemical sensitivity screen to evaluate how silibinin modulates the sensitivity of these cells to a variety of chemotherapeutics (Figure 2; Figure S1). The EML-ALK fusion CCL-185IG derivative acquired a notably enhanced responsiveness to silibinin when co-treated with the dihydrofolate reductase inhibitor aminopterin - the original clinical anti-folate-and azaserine, a glutaminefructose-6-phosphate transaminase (GFPT) inhibitor that blocks N-linked glycosylation and the hexosamine biosynthesis pathway. Silibinin co-treatment also prevented EML-ALK fusion-driven resistance to the platinum agents cisplatin and carboplatin. Further studies are warranted to evaluate whether EGFR- and ALK-positive tumors acquire sensitivity to certain silibinin-containing chemotherapeutic combinations once they are resistant to EGFR- and ALK-TKIs and available TKI options are exhausted. 

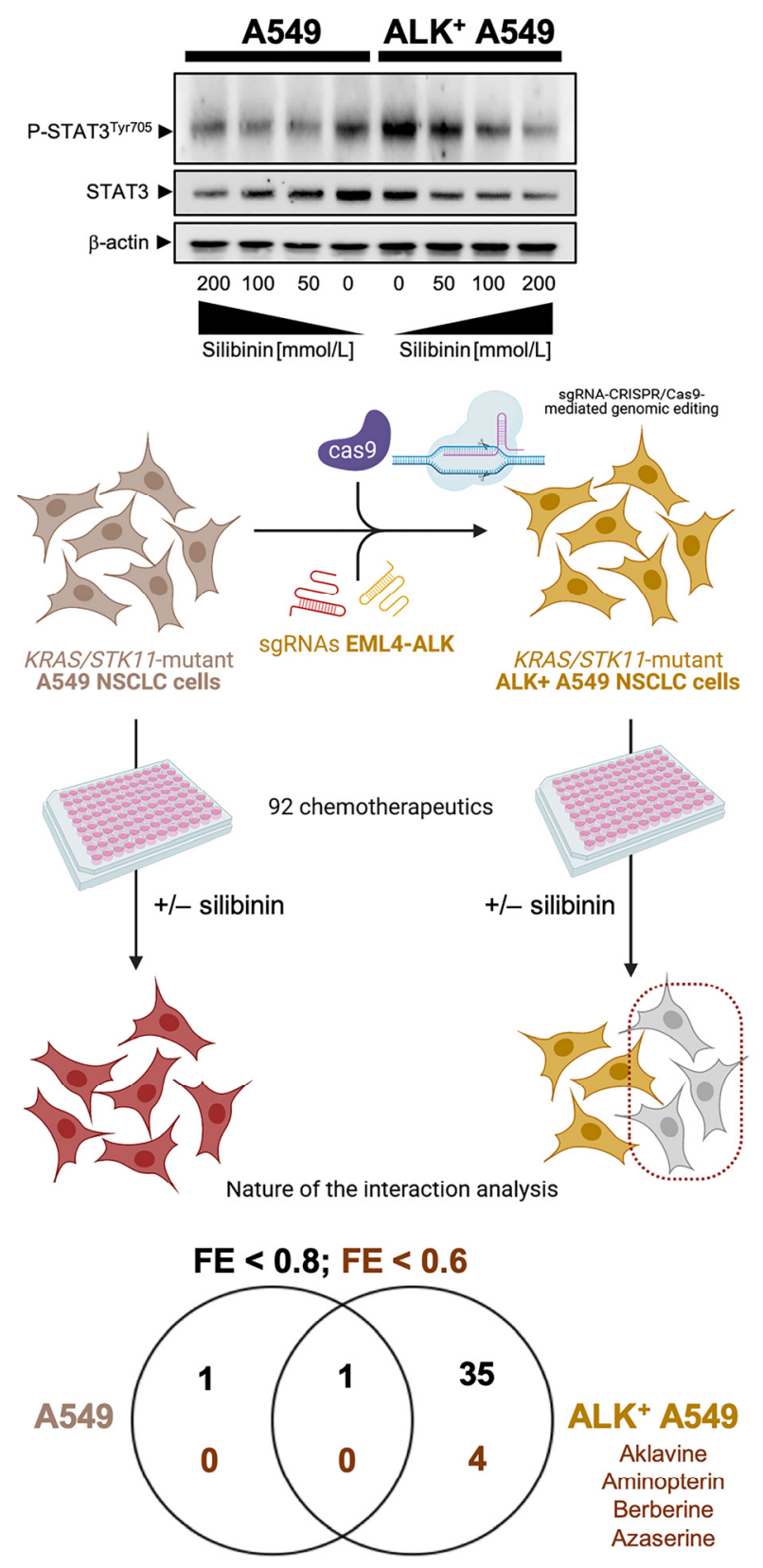

Figure 2. EML4-ALK-dependent chemosensitizing effects of silibinin in non-small cell lung cancer cells. We utilized the Phenotypic Microarray system, marketed and sold by Biolog (www.biolog.com, access date: 30 May 2021) to measure the sensitivity of an A549 non-small cell lung cancer (NSCLC) cell line with an EML4-ALK fusion isogenic oncogene (https:/ / www.nature.com/articles/d42473-0 19-00011-z, access date: 30 May 2021) to a variety of growth inhibitors (in total, 92) in microplates (PM-M11 to PM-M14). This approach enables the simultaneous testing of tens of phenotypes and the identification of shared versus selective sensitivities to a wide variety of mechanistically distinct drugs. We chose a silibinin concentration of $100 \mu \mathrm{mol} / \mathrm{L}$, which was notably lower than the $\mathrm{IC}_{50}$ value against A549 cells and consistently reduced cell viability by less than $5 \%$ in multiple experiments using the colorimetric redox-sensitive dye employed in the Biolog technology. A set of "negative" control plates cultured in the presence of the silibinin vehicle DMSO were used to assess the inherent response of A549/ALK+ A549 cells to growth inhibitors. A set of "positive" plates cultured in the presence of $100 \mu \mathrm{mol} / \mathrm{L}$ silibinin served to assess the nature of the interaction between silibinin and the 92 drugs pre-loaded in the 96-well plates (4 graded concentrations/each). We assessed the nature of the cytotoxic responses based on synergistic, additive, or antagonistic categories using an arbitrarily defined ratio of observed effect/theoretical effect, the so-called fractional effect (FE) 
method (Figure S1). Briefly, the theoretical effect of the combination was calculated by adding the effects of each drug used alone at the concentration tested in the combination to that obtained when silibinin was tested alone (i.e., "negative" control plates + effect of silibinin as single agent). This theoretical effect was compared with the actual effect obtained during the combinatorial experiment ("positive" plates, i.e., drugs in combination with silibinin) carried out strictly in parallel. The different interactions were then defined as follows: "additivity" was an observed effect equal to the theoretical effect, and the ratio between them ranged between 0.8 and 1.2; "synergy" was an observed effect higher than the theoretical effect, and the ratio between them was less than 0.8; and "antagonism" was an observed effect lower than the theoretical effect, and the ratio between them was more than 1.2. The interaction between silibinin and a given drug was initially scored as "synergistic" when at least two FEs were $<0.8$. A truly synergistic interaction was scored when data sets were re-assessed using a stricter threshold criterion (i.e., at least two FEs were $<0.6$ ). The representative immunoblots presented in the upper part of the figure show Western blot analyses of cell lysates from A549 parental cells and ALK + A549 derivatives cultured in the absence or presence of graded concentrations of silibinin $(24 \mathrm{~h})$ immunoblotted with anti-phospho-STAT3 ${ }^{\text {Tyr705, anti-total }}$ STAT3, and anti- $\beta$-actin. Created with BioRender. (+/ - , plus/minus).

\subsection{Silibinin and Lung Cancer Metastatic Traits \\ 5.2.1. Inhibition of Cell Invasion}

Early studies observed that, in the absence of cytotoxic effects, silibinin could exert dose- and time-dependent inhibitory effects on the invasion and motility (but not on the adhesion) of highly metastatic NSCLC cell models [57]. Mechanistic studies revealed that silibinin decreased the expression of metalloproteinase-2 (MMP-2) and urokinase plasminogen activator, and enhanced the expression of tissue inhibitor of metalloproteinase (TIMP-2) [57]. The negative effect of silibinin on NSCLC invasiveness and metastasis, by changing the balance between MMPs and TIMPs in favor of the inhibitors, appeared to occur downstream of its ability to inactivate PI3K-AKT and MAPK signaling pathways [58,59]. More recent mechanistic studies have established, however, that the mechanism of action of silibinin against MMPs might causally involve silibinin-driven inhibition of STAT3 activation and nuclear translocation [60].

\subsubsection{Inhibition of Epithelial-to-Mesenchymal Transition}

Beyond MMPs and TIMPs, which have key roles in tumor cell invasion and metastasis by digesting the basement membrane and extracellular matrix components, silibinin can target lung cancer metastastic traits by inhibiting EMT per se. EMT is a highly complex molecular reprogramming process whereby cells lose their epithelial features and acquire a mesenchymal phenotype, allowing them to detach from the primary tumor, invade adjacent stroma, enter systemic circulation, and form distant metastasis. EMT also contributes to tumor aggressiveness by enhancing the resistance of cancer cells to chemotherapy, radiation therapy and targeted therapy, which is a key feature of tumor- and metastasis-initiating CSCs (reviewed in [61-63]).

Various mechanisms of resistance to EGFR- and ALK-TKIs in NSCLC are linked to the activation of EMT-like phenomena, irrespective of the EGFR and ALK mutation status [64-72]. Silibinin has been reported to restore drug sensitivity to EGFR-mutant NSCLC xenografts with EMT-driven resistance to gefitinib and erlotinib. Silibinin treatment also impedes the regrowth of gefitinib-unresponsive xenograft NSCLC tumors, resulting in drastic tumor growth prevention in vivo [48]. Similarly, silibinin was found to fully activate a reciprocal mesenchymal-to-epithelial transition in erlotinib-refractory cells and prevent the highly migratogenic phenotype of erlotinib-resistant NSCLC cells [49].

The ability of silibinin to block EMT and to impede the acquisition of transcriptional and morphological behavior of transitioning cells appears to occur in a multi-faceted manner. Silibinin can fine-tune the epigenetic dynamics of key EMT-driven events. For 
instance, silibinin was found to fully reverse the EMT-related high miR-21/low miR-200c microRNA signature and repress the expession of the mesenchymal markers SNAIL, ZEB1, and N-cadherin in erlotinib-refractory NSCLC human xenografts [49]. Because epigenetic modulation of the miR-21 oncogene and the miR-200c tumor suppressor is causally associated with transition to a CSC-like state [73-77], these findings indicated that silibinin might regulate the epigenetic plasticity of microRNAs, contributing to the evolving and adapting phenotypes of lung carcinomas. Indeed, combinatorial treatment with silibinin and histone deacetylase and DNA methyltransferase inhibitors modulated EMT events in NSCLC cell lines, including reversion of the inverse expression pattern of ZEB1 and E-cadherin, tempering their migratory and invasive potential [78]. In the same line, silibinin was recently shown to suppress migration, invasion, and EMT expression by repressing the expression of Rhomboid domain containing 1, a well-known promoter of cell migration, invasion, EMT, and stem cell-like phenotypes in multiple cancer types including lung cancer [79]. The initially reported capacity of silibinin to target EGFR signaling [46] has been shown to involve the suppression of the downstream matrix remodeling enzyme lysyl oxidase, a key contributor to the early steps of metastastic colonization by enhancing tumor invasion, migration, and the formation of pre-metastatic niche [80-83]. Silibinin in combination with EGFR blockade prevented NSCLC cell migration in vitro and tumor metastasis in an orthotopic implantation metastasis model by targeting the EGFR/LOX pathway [84]. In contrast to other EMT-targeting compounds, a recent transcriptomic profiling study revealed that de novo responsiveness of NSCLC cells to silibinin does not correlate with their intrinsic EMT stage [85]. Rather, silibinin responsiveness appears to be linked to a subnetwork of tightly interconnected genes of cell cycle, survival, and stress response (e.g., BIRC5, FOXM1, and BRCA1) whose transcriptomic pattern is under control of STAT3 [85].

\subsubsection{Inhibition of Brain Metastasis}

Our resent findings have positioned silibinin as a successful therapy to treat established brain metastasis in patients with NSCLC. In 2016, we presented the first evidence for oral silibinin as part of a bioavailable formulation with predicted capacity to cross the blood-brain barrier (BBB) [86], which resulted in significant clinical and radiological improvement of brain metastasis in two patients with poor performance status that progressed after whole brain radiotherapy and chemotherapy [87]. The suppressive effects of silibinin on progressive brain metastasis, which included a marked reduction in peritumoral brain edema, occurred in the absence of changes to the primary lung tumor outgrowth [87]. We then compared our clinical series of patients with NSCLC treated with the silibinin-containing nutraceutical Legasi ${ }^{\circledR}(n=18$; single-agent silibinin $n=3$ and silibinin plus additional therapy $n=15$ ) with patients treated at the same institution who completed whole-brain radiation therapy for NSCLC brain metastasis and who received systemic therapy but not silibinin $(n=38)$. In such a small cohort, silibinin demonstrated highly significant clinical activity with a $75 \%$ overall response rate in the brain including three complete responses and ten partial responses [88]. Indeed, the patients receiving silibinin as palliative care $(n=3)$ benefited from additional treatment lines as a result of their general status improvement and magnetic resonance imaging-based brain responses. The overall survival from the diagnosis of brain metastasis was significantly superior in the cohort of patients treated with the silibinin-containing nutraceutical (15.5 months) than in the control cohort (4.0 months), a trend that was maintained when patients with EGFR and ALK oncogenic driver mutations were excluded from the analysis [88].

A subpopulation of reactive astrocytes surrounding brain metastases has been identified that is driven by STAT3 activation and is characterized by nuclear accumulation of phospho-active STAT3 $[88,89]$. NSCLC metastatic tumor cells that have initiated a brain macro-metastasis secrete various factors that trigger astrocytes in the surrounding area to become reactive with enhanced STAT3 activation. In turn, phospho-STAT3+ reactive astrocytes produce cytokines and other factors to escape innate and adaptive anti-tumor 
immune responses [88]. Investigations into the molecular mechanisms involved in the aforementioned clinico-molecular activities of silibinin revealed that silibinin efficiently suppresses the ability of brain metastastic NSCLC cells to co-opt a pro-metastatic program driven by STAT3 in a subpopulation of reactive astrocytes surrounding metastatic lesions [88]. Blocking STAT3 signaling in reactive astrocytes in the brain microenvironment with silibinin reduced brain metastasis growth and disease burden.

\section{STAT3: A primary Tumor-Cell Intrinsic and Microenvironmental Target of Silibinin in Lung Cancer}

Central to the tumor cell-intrinsic and microenvironmental effects of silibinin in lung cancer is the transcriptional factor STAT3 (Figure 3).
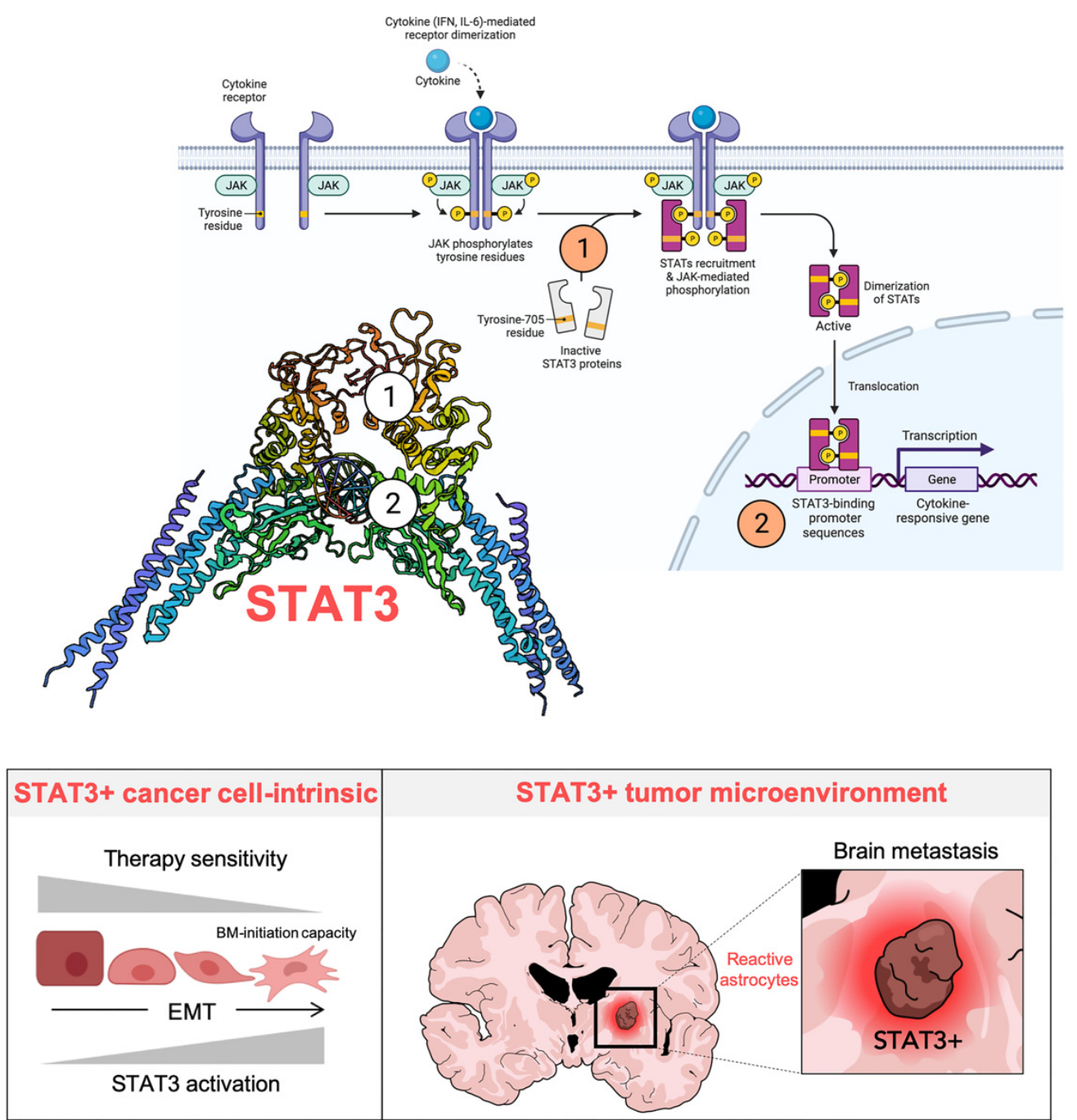

Figure 3. Silibinin mechanism of action in lung cancer: A STAT3-centric view. Aberrant activation of JAK/STAT3 signaling, in particular STAT3, participates in the initiation, development, and therapeutic resistance of lung cancer via promotion of proliferation, survival, inflammation, angiogenesis, and metastasis. Silibinin is a unique blocker of the JAK/STAT3 signal transduction cascade that operates as a bimodal SH2- and DBD-targeting direct STAT3 inhibitor (STAT3i) while sparing JAK activity. STAT3 participates in multiple layers of the EMT regulatory network, and feedback activation of STAT3 is a common cause of resistance to many chemotherapies and targeted cancer therapies. At the lung cancer cell-intrinsic level, silibinin-containing combinatorial treatments can overcome drug resistance and reduce the brain metastasis-initiating capacity of lung cancer cells. Brain metastasis cells promote the co-option of a pro-metastatic program driven by STAT3 activation in a subpopulation of reactive astrocytes surrounding metastatic lesions. Blocking microenvironmental STAT3 signaling in reactive astrocytes with silibinin reduces the growth of brain metastases from primary NSCLC tumors, even at advanced stages of colonization. Created with BioRender. 


\subsection{Identification of Silibinin as a Direct STAT3 Inhibitor}

We recently combined experimental, computational, and clinical efforts to investigate how silibinin imparts therapeutic benefits to patients with lung cancer by targeting STAT3. We found that the primary mechanism of action of silibinin involves a unique, bimodal Src Homology-2 domain (SH2; STAT3 dimerization) and DBD (STAT3 DNA-binding domain)targeted inhibitory effect against STAT3 [89]. Biochemical approaches demonstrated that silibinin attenuates the tyrosine (Y705) phospho-activation in GFP-STAT3 genetic fusions without significantly altering the kinase activity of the STAT3 upstream kinases JAK1 and JAK2. Once we discarded the possibility that silibinin was a direct JAK inhibitor, we performed a comparative computational study based on docking and molecular dynamics simulations over structurally diverse STAT3 inhibitors. Silibinin was predicted to show a unique mode of high-affinity binding to the $\mathrm{SH} 2$ domain, partially overlapping with the cavity occupied by other direct STAT3 inhibitors to indirectly prevent Y705 phosphorylation. Silibinin treatment of cultured NSCLC cells prevented IL-6 inducible, constitutive, and acquired feedback activation of STAT3 [89]. In silico approaches also predicted that silibinin could directly bind with high affinity to the STAT3 DBD, uniquely involving the establishment of direct interactions with DNA. Because STAT3 dimerization is mediated by the interaction between a phospho-Y705-containing peptide and the $\mathrm{SH} 2$ domain, which is essential for its DNA binding and subsequent transcriptional activity, the demonstration that silibinin prevented STAT3 nuclear translocation, blocked the binding of activated STAT3 to its consensus DNA sequence, and suppressed STAT3-directed transcriptional activity further confirmed the molecular behavior of silibinin as a bona fide direct STAT3 inhibitor [89].

\subsection{STAT3-Targeted Cancer Cell-Intrinsic and Microenvironmental Effects of Silibinin}

The so-called STAT3C mutant, a constitutively active form of STAT3, has been employed to confirm STAT3 as a primary tumor-cell intrinsic and microenvironmental target of silibinin [90,91]. This mutant has substitutions of the A661 and N663 residues of the SH2 domain with cysteines, allowing a disulfide bond to form between two unphosphorylated STAT3 monomers; yet, it still requires Y705 phosphorylation for functional activation via promotion of maximal DNA binding affinity and protection from inactivation by phosphatases (slower off-rate), resulting in the accumulation of transcriptionally active STAT3 dimer complexes. In silico modeling of the conformation of silibinin in the binding pocket within the SH2 domain of native and A662C/N664C-mutant structures predicted a reduced ability of silibinin to bind with high affinity to the SH2 domain of the STAT3C mutant [88]. Accordingly, cancer cells engineered to overexpress STAT3C remain largely unresponsive to the inhibitory effects of silibinin on key transcriptional and phenotypic targets of STAT3 (e.g., c-myc expression and metabolic reprogramming) [88,92]. Moreover, overexpression of constitutively active STAT3C in astrocytes suffices to prevent the regulatory effects of silibinin, thus demonstrating the STAT3-dependency on the phenotypic effects of silibinin towards the microenvironment of NSCLC brain metastasis [88].

We should acknowledge that STAT3 might also represent a potential therapeutic target in the early prevention/treatment of lung-to-brain metastases. Using patient-derived stem cell lines from lung-to-brain metastases, Singh and colleagues identified STAT3 and miR-21 as cooperative regulators of stemness, migration, and brain-metastasis initiation capacity of lung cancer cells [93]. The dual STAT3/miR-21 inhibitory activity of silibinin [49,89] might therefore be revisited in terms of its ability to target not only the growth of established brain metastasis, but also the early machinery activated by brain-metastasis initiating cells to escape the primary lung tumor, migrate, and invade the neural niche.

Taking advantage of the CRISPR/Cas9-edited homozygous Y705F mutant STAT3 protein in DLD-1 1 STAT3Y705F/Y705F cells, we recently performed a chemical sensitivity screen to evaluate how STAT3 phosphorylation at Tyr705 might be required for silibinin-induced chemosensitization events (Figure 4; Figure S2). The ability of silibinin to synergistically cooperate with aminopterin was lost in DLD-1 ${ }^{\text {STAT3Y705F/Y705F }}$ cells, thereby suggesting 
that the nature of the interaction more likely relied on the capacity of aminopterin to operate as a JAK/STAT inhibitor independently of its primary dihydrofolate reductase target [94]. The synergistic interaction between silibinin and the GFPT inhibitor azaserine was, however, only partially prevented when the ability of silibinin to block IL6-induced Y705 phosphorylation was abolished, suggesting that silibinin may directly operate on the $\mathrm{N}$-linked glycosylation/hexosamine biosynthesis pathway.

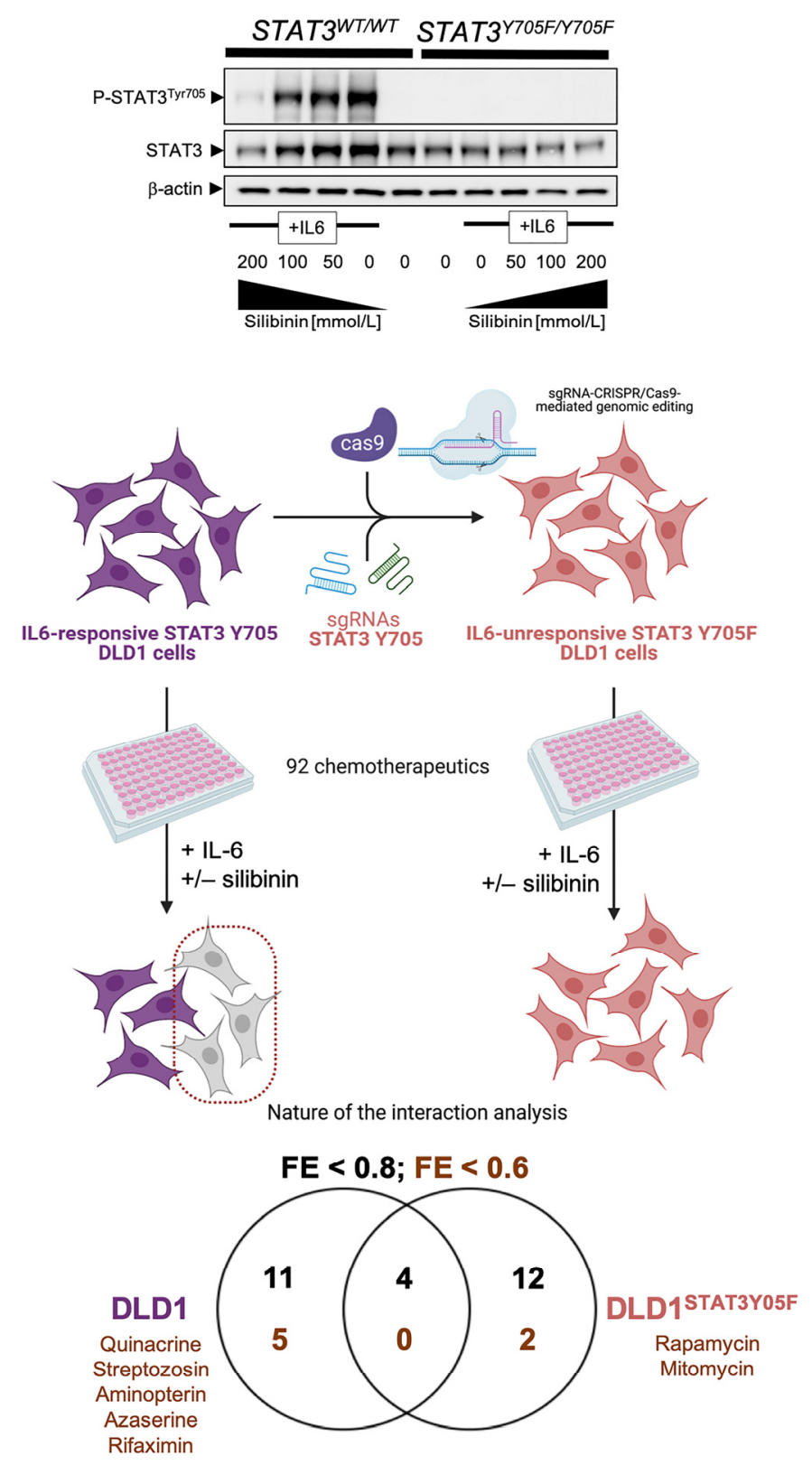

Figure 4. STAT3 Tyr705-dependent chemosensitizing effects of silibinin. We utilized the Phenotypic Microarray system, marketed and sold by Biolog (www.biolog.com, access date: 30 May 2021), to measure the sensitivity of DLD1 (STAT3WT/WT) cancer cells and a homozygous STAT3 Y705F/Y705F knock-in isogenic derivative (Horizon Discovery, Cat.\# HD 115-016) to a wide variety of 92 growth inhibitors in microplates (PM-M11 to PM-M14) following an identical procedure to that described in Figure 2. The representative immunoblots presented in the upper part of the figure show western blot analyses of cell lysates from DLD1 STAT3 $3^{W T / W T}$ parental cells and DLD1 STAT3 ${ }^{\text {Y705F/Y705F }}$ derivatives cultured in the absence or presence of graded concentrations of silibinin $(24 \mathrm{~h})$ immunoblotted with anti-phospho-STAT3 ${ }^{\text {Tyr705 }}$, anti-total STAT3, and anti- $\beta$-actin. Created with BioRender. (+/-, plus/minus). 


\subsection{Silibinin versus Other Natural Products Exhibiting STAT3 Inhibitory Activity}

Natural products have historically been an important resource of chemical scaffolds and bioactive substructures in the discovery of STAT3 inhibitors. A large list of natural products have been reported in the literature to exhibit STAT3 inhibitory activity, including curcumin, berbamine, resveratrol, caffeic acid, capsaicin, cryptotanshinone, celastrol, avicin $\mathrm{D}$, withaferin A, betulinic acid, ursolic acid, oleanolic acid, cucurbitacin, diosgenin, emodin, honokiol, flavopiridol, evodiamine, carbazole, sanguarine, and guggulsterone (reviewed in [95]). Despite the fact some of these natural products have reached clinical development, the precise STAT3-targeting mechanism(s) of action of the majority has yet to be fully elucidated, as they might inhibit STAT3 indirectly and are expected to block several targets. Resveratrol (3,5,4'-trihydroxystilbene), a widely studied polyphenolic compound found in red grapes and several other plants, was originally reported to inhibit constitutive and IL-6-induced STAT3 activity in multiple tumor cell types [96,97]. Although thought to be primarily a STAT3 inhibitor, resveratrol has also been found to modulate STAT1 activity, thus highlighting that selectivity for STAT3 over STAT1 should be carefully considered for the development of natural product-like STAT3 inhibitors [98]. Comparative in silico docking studies aimed to study the binding specificity of STAT inhibitors established that those compounds exclusively targeting the highly conserved phosphotyrosine binding pocket of the SH2 domain should be expected to lack selectivity towards STAT3, given that STAT1 and STAT3 have identical active residues at this site $[99,100]$. The predicted ability of silibinin to bind the $\mathrm{SH} 2$ activation/dimerization domain relies on its capacity to overlap with up to $60 \%$ of all the residues involved in the binding mode of a wide variety of structurally diverse STAT3is, but showing a unique binding mode [89]. By targeting the SH2 domain of STAT3 monomers, silibinin can prevent not only binding of STAT3 to activated cell surface receptors, but also to block cytosolic STAT3 dimerization, thereby preventing nuclear accumulation of phospho-active STAT3 [89]. Importantly, the ability of silibinin to inhibit the transcriptional activity of STAT3 in cells does not rely exclusively on its ability to antagonize STAT3 dimerization in the cytosol and STAT3 tyrosine phosphorylation, but also involves an additional direct inhibition of STAT3 via binding to the DBD irrespective of the STAT3 dimerization status [89]. Accordingly, silibinin is the best-positioned natural lead for a new generation of bimodal SH2- and DBD-targeting STAT3is that might become incorporated into the clinical management of lung tumors. While the clinical value of silibinin as a bona fide anti-lung cancer therapy remains uncertain with respect to its bioavailability and BBB permeability, we are rapidly accumulating information to help identify the best silibinin formulation that would reach cancer tissues and have clinical activity, including a meaningful formulation against lung brain metastases [86].

\section{Silibinin and Lung Cancer: The Past, Present, and Future (a Corollary)}

The milk thistle, whose main bioactive component is the flavonolignan silibinin, was originally described as a remedy for the bites of poisonous snakes in "De Materia Medica" by Dioscorides (50 A.D.). Almost 2000 years later, new formulations of silibinin are being clinically developed to protect liver against injury from mushroom poisoning or lipotoxic injury in fatty liver diseases. An ever-expanding number of studies are exploring the capacity of silibinin to exert inhibitory activity against cultured cancer cells and tumor xenografts, to enhance the efficacy of other therapeutic agents, and to overcome the emergence of cancer drug resistance in pre-clinical lung cancer models [101]. Although silibinin has shown chemopreventive and chemosensitizing activity against various human malignancies through multiple molecular pathways [102,103], lung cancer is becoming the paradigm for how the deconstruction of a central mechanism of action of silibinin (i.e., STAT3) has enabled this natural compound to reach clinical development. Perhaps more importantly, silibinin-driven STAT3 blockade holds immense promise in areas of highly unmet clinical need such as lung cancer brain metastasis, which portend a poor prognosis and have very few therapeutic options $[87,88]$. Here, we have reviewed the historical context and provided new translational insights into how an old hepatoprotective remedy 
could be viewed as a novel lung cancer-preventive and therapeutic biomolecule, which might serve as a guiding example for other tumor types in the future.

Forthcoming studies should accept the challenge of developing silibinin and/or nextgeneration silibinin derivatives with improved lung cancer-preventing and treatment traits. We need to disentangle how silibinin prevents the generation of metastasis-initiating subpopulations within chemoresistant and/or TKI-tolerant lung tumors. In this regard, it would be important to elucidate the molecular mechanisms through which silibinin prevents brain tropism of metastatic lung cancer cells by targeting their capacities to self-renew and/or remodel the tumor microenvironment. We also need to molecularly deconstruct and functionally monitor the ability of silibinin to regulate the immune-escape mechanisms of lung cancer cells (and/or brain metastasis-initiating lung cancer cells), to influence the response to T-cells, and to interact with immune checkpoint inhibitors (e.g., anti-CTLA-4 and anti-PD-1/PD-L1 antibodies) in therapy-resistant lung carcinomas. Finally, we need to evaluate how silibinin interacts with the BBB to impede transmigration of brain metastasisinitiating cells and/or to regulate the metabolism and brain accumulation of targeted therapies. The unraveling of an unforeseen, selective vulnerability of silibinin-treated tumor cells to the hexosamine biosynthesis pathway inhibitor azaserine using genomically edited isogenic models might exemplify how to exploit the therapeutic usage of silibinin in combination with certain targetable weaknesses in specific subtypes of lung cancer (e.g., KRAS/STK11 co-mutant tumors with dependence on the hexosamine biosynthesis pathway through GFPT2 [104]). Using silibinin as a lead structure to guide development, it would be possible to use synthetic chemistry approaches to generate a battery of silibinin derivatives with enhanced radiosensitizing capacity and augmented brain targeting. These approaches, together with the utilization of clinically relevant models of lung cancer to test the efficacy and toxicity of silibinin and/or silibinin derivatives, should allow for the incorporation of this flavonolignan as a modern therapeutic approach for medical management of human lung cancer.

\section{Conclusions}

- The deconstruction and validation of a central mechanism of action of silibinin (i.e., STAT3) has enabled this natural compound to reach clinical development in lung cancer;

- Silibinin is capable of reaching target cancer tissues and groundbreakingly provides survival advantages to lung cancer patients with brain metastasis when used as part of formulations with an optimized oral bioavailability;

- Critical drivers for silibinin responsiveness versus resistance in specific lung cancer molecular subtypes can be identified using CRISPR-based functional genomics;

- Lessons from natural chemistry of silibinin can offer novel approaches for synthetic chemistry in lung cancer drug discovery.

Supplementary Materials: The following are available online at https://www.mdpi.com/article/10.339 0/ph14060559/s1, Figure S1. (a) Original uncropped immunoblots for Figure 2. (b) Original raw data of the phenotypic microarray system analyzed in Figure 2. Figure S2. (a) Original uncropped immunoblots for Figure 4. (b) Original raw data of the phenotypic microarray system analyzed in Figure 4.

Author Contributions: S.V., J.B.-B. and J.A.M. conceived the scope of the manuscript. S.V., E.C., J.B.-B. and J.A.M. drafted and edited the final version of the manuscript. S.V., E.C., V.R.-T., V.M., J.J., and J.B.-B. helped with formatting of the manuscript, schematics and literature search and selection. All authors have read and agreed to the published version of the manuscript.

Funding: Work in the Menendez laboratory is supported by the Spanish Ministry of Science and Innovation (grants SAF2016-80639-P and PID2019-10455GB-I00, Plan Nacional de 1+D+I, founded by the European Regional Development Fund, Spain) and by an unrestricted research grant from the Fundació Oncolliga Girona (Lliga catalana d'ajuda al malalt de càncer, Girona). Elisabet Cuyàs is a recipient of a research contract "Miguel Servet" (CP20/00003) from the Instituto de Salud Carlos III, Spanish Ministry of Science and Innovation (Spain). Joaquim Bosch-Barrera is the recipient of Research Grants from Grupo Español de Cáncer de Pulmón (GECP), La Marató de TV3 foundation (201906), and the Health Research and Innovation Strategic Plan (SLT006/17/114; PERIS 2016-2020; 
Pla stratègic de recerca i innovació en salut; Departament de Salut, Generalitat de Catalunya). The authors would like to heartily thank König (www.konig.cat, access date: 30 May 2021) for their generous donation to fund our cancer research on silibinin in Girona.

Institutional Review Board Statement: Not applicable.

Informed Consent Statement: Not applicable.

Data Availability Statement: The data that support the findings of this study are available from the corresponding authors, upon reasonable request.

Acknowledgments: The authors would like to thank Kenneth McCreath for editorial support.

Conflicts of Interest: Joaquim Bosch-Barrera reports grants and personal fees from Roche-Genentech, grants from Pfizer and Pierre Fabre, and personal fees from MSD, BMS, AstraZeneca, BoehringerIngelheim, and Novartis, outside the submitted work. The authors declare that the research was conducted in the absence of any commercial or financial relationships that could be construed as a potential conflict of interest.

\section{References}

1. Middleton, E., Jr.; Kandaswami, C.; Theoharides, T.C. The effects of plant flavonoids on mammalian cells: Implications for inflammation, heart disease, and cancer. Pharmacol. Rev. 2000, 52, 673-751. [PubMed]

2. Romano, B.; Pagano, E.; Montanaro, V.; Fortunato, A.L.; Milic, N.; Borrelli, F. Novel insights into the pharmacology of flavonoids. Phytother. Res. 2013, 27, 1588-1596. [CrossRef] [PubMed]

3. Barrajón-Catalán, E.; Herranz-López, M.; Joven, J.; Segura-Carretero, A.; Alonso-Villaverde, C.; Menéndez, J.A.; Micol, V. Molecular promiscuity of plant polyphenols in the management of age-related diseases: Far beyond their antioxidant properties. Adv. Exp. Med. Biol. 2014, 824, 141-159.

4. Howitz, K.T.; Sinclair, D.A. Xenohormesis: Sensing the chemical cues of other species. Cell 2008, 133, 387-391. [CrossRef]

5. Menendez, J.A.; Joven, J.; Aragonès, G.; Barrajón-Catalán, E.; Beltrán-Debón, R.; Borrás-Linares, I.; Camps, J.; Corominas-Faja, B.; Cufí, S.; Fernández-Arroyo, S.; et al. Xenohormetic and anti-aging activity of secoiridoid polyphenols present in extra virgin olive oil: A new family of gerosuppressant agents. Cell Cycle 2013, 12, 555-578. [CrossRef]

6. Kim, N.C.; Graf, T.N.; Sparacino, C.M.; Wani, M.C.; Wall, M.E. Complete isolation and characterization of silybins and isosilybins from milk thistle (Silybum marianum). Org. Biomol. Chem. 2003, 1, 1684-1689. [CrossRef]

7. Gazák, R.; Walterová, D.; Kren, V. Silybin and silymarin-New and emerging applications in medicine. Curr. Med. Chem. 2007, 14, 315-338. [CrossRef] [PubMed]

8. Lee, J.I.; Narayan, M.; Barrett, J.S. Analysis and comparison of active constituents in commercial standardized silymarin extracts by liquid chromatography-electrospray ionization mass spectrometry. J. Chromatogr. B Analyt. Technol. Biomed. Life Sci. 2007, 845, 95-103. [CrossRef]

9. Abenavoli, L.; Capasso, R.; Milic, N.; Capasso, F. Milk thistle in liver diseases: Past, present, future. Phytother. Res. 2010, 24, 1423-1432. [CrossRef]

10. Hackett, E.S.; Twedt, D.C.; Gustafson, D.L. Milk thistle and its derivative compounds: A review of opportunities for treatment of liver disease. J. Vet. Intern. Med. 2013, 27, 10-16. [CrossRef] [PubMed]

11. Bijak, M. Silybin, a Major Bioactive Component of Milk Thistle (Silybum marianum L. Gaernt.) —Chemistry, Bioavailability, and Metabolism. Molecules 2017, 22, 1942.

12. Abenavoli, L.; Izzo, A.A.; Milić, N.; Cicala, C.; Santini, A.; Capasso, R. Milk thistle (Silybum marianum): A concise overview on its chemistry, pharmacological, and nutraceutical uses in liver diseases. Phytother. Res. 2018, 32, 2202-2213. [CrossRef] [PubMed]

13. Biedermann, D.; Vavř́ková, E.; Cvak, L.; Křen, V. Chemistry of silybin. Nat. Prod. Rep. 2014, 31, 1138-1157. [CrossRef]

14. Vargas-Mendoza, N.; Madrigal-Santillán, E.; Morales-González, A.; Esquivel-Soto, J.; Esquivel-Chirino, C.; García-Luna, Y.; González-Rubio, M.; Gayosso-de-Lucio, J.A.; Morales-González, J.A. Hepatoprotective effect of silymarin. World J. Hepatol. 2014, 6, 144-149. [CrossRef]

15. Saller, R.; Meier, R.; Brignoli, R. The use of silymarin in the treatment of liver diseases. Drugs 2001, 61, 2035-2063. [CrossRef] [PubMed]

16. Saller, R.; Melzer, J.; Reichling, J.; Brignoli, R.; Meier, R. An updated systematic review of the pharmacology of silymarin. Forsch. Komplementmed. 2007, 14, 70-80. [CrossRef]

17. Loguercio, C.; Festi, D. Silybin and the liver: From basic research to clinical practice. World J. Gastroenterol. 2011, 17, $2288-2301$. [CrossRef]

18. Federico, A.; Dallio, M.; Loguercio, C. Silymarin/Silybin and Chronic Liver Disease: A Marriage of Many Years. Molecules 2017, 22, 191. [CrossRef]

19. Tajmohammadi, A.; Razavi, B.M.; Hosseinzadeh, H. Silybum marianum (milk thistle) and its main constituent, silymarin, as a potential therapeutic plant in metabolic syndrome: A review. Phytother. Res. 2018, 32, 1933-1949. [CrossRef] 
20. Gillessen, A.; Schmidt, H.H. Silymarin as Supportive Treatment in Liver Diseases: A Narrative Review. Adv. Ther. 2020, 37, 1279-1301. [CrossRef]

21. Wellington, K.; Jarvis, B. Silymarin: A review of its clinical properties in the management of hepatic disorders. BioDrugs 2001, 15, 465-489. [CrossRef] [PubMed]

22. Singh, R.P.; Agarwal, R. Mechanisms and preclinical efficacy of silibinin in preventing skin cancer. Eur. J. Cancer 2005, 41, 1969-1979. [CrossRef]

23. Prasad, R.R.; Paudel, S.; Raina, K.; Agarwal, R. Silibinin and non-melanoma skin cancers. J. Tradit. Complement. Med. 2020, 10, 236-244. [CrossRef] [PubMed]

24. Singh, R.P.; Agarwal, R. Prostate cancer prevention by silibinin. Curr. Cancer Drug Targets 2004, 4, 1-11. [CrossRef] [PubMed]

25. Singh, R.P.; Agarwal, R. Prostate cancer chemoprevention by silibinin: Bench to bedside. Mol. Carcinog. 2006, 45, 436-442. [CrossRef]

26. Zhao, J.; Agarwal, R. Tissue distribution of silibinin, the major active constituent of silymarin, in mice and its association with enhancement of phase II enzymes: Implications in cancer chemoprevention. Carcinogenesis 1999, 20, 2101-2108. [CrossRef]

27. Mateen, S.; Raina, K.; Agarwal, R. Chemopreventive and anti-cancer efficacy of silibinin against growth and progression of lung cancer. Nutr. Cancer 2013, 65 (Suppl. 1), 3-11. [CrossRef] [PubMed]

28. Singh, R.P.; Agarwal, R. Cosmeceuticals and silibinin. Clin. Dermatol. 2009, 27, 479-484. [CrossRef]

29. Slaga, T.J. SENCAR mouse skin tumorigenesis model versus other strains and stocks of mice. Environ. Health Perspect. 1986, 68, 27-32. [CrossRef] [PubMed]

30. Ewing, M.W.; Conti, C.J.; Kruszewski, F.H.; Slaga, T.J.; DiGiovanni, J. Tumor progression in Sencar mouse skin as a function of initiator dose and promoter dose, duration, and type. Cancer Res. 1988, 48, 7048-7054.

31. Sharma, G.; Singh, R.P.; Chan, D.C.; Agarwal, R. Silibinin induces growth inhibition and apoptotic cell death in human lungcarcinoma cells. Anticancer Res. 2003, 23, 2649-2655.

32. Singh, R.P.; Mallikarjuna, G.U.; Sharma, G.; Dhanalakshmi, S.; Tyagi, A.K.; Chan, D.C.; Agarwal, C.; Agarwal, R. Oral silibinin inhibits lung tumor growth in athymic nude mice and forms a novel chemocombination with doxorubicin targeting nuclear factor kappaB-mediated inducible chemoresistance. Clin. Cancer Res. 2004, 10, 8641-8647. [CrossRef]

33. Yan, Y.; Wang, Y.; Tan, Q.; Lubet, R.A.; You, M. Efficacy of deguelin and silibinin on benzo(a)pyrene-induced lung tumorigenesis in A/J mice. Neoplasia 2005, 7, 1053-1057. [CrossRef]

34. Singh, R.P.; Deep, G.; Chittezhath, M.; Kaur, M.; Dwyer-Nield, L.D.; Malkinson, A.M.; Agarwal, R. Effect of silibinin on the growth and progression of primary lung tumors in mice. J. Natl. Cancer Inst. 2006, 98, 846-855. [CrossRef] [PubMed]

35. Chittezhath, M.; Deep, G.; Singh, R.P.; Agarwal, C.; Agarwal, R. Silibinin inhibits cytokine-induced signaling cascades and down-regulates inducible nitric oxide synthase in human lung carcinoma A549 cells. Mol. Cancer Ther. 2008, 7, 1817-1826. [CrossRef]

36. Tyagi, A.; Singh, R.P.; Ramasamy, K.; Raina, K.; Redente, E.F.; Dwyer-Nield, L.D.; Radcliffe, R.A.; Malkinson, A.M.; Agarwal, R. Growth inhibition and regression of lung tumors by silibinin: Modulation of angiogenesis by macrophage-associated cytokines and nuclear factor-kappaB and signal transducers and activators of transcription 3. Cancer Prev. Res. (Phila) 2009, 2, 74-83. [CrossRef]

37. Ramasamy, K.; Dwyer-Nield, L.D.; Serkova, N.J.; Hasebroock, K.M.; Tyagi, A.; Raina, K.; Singh, R.P.; Malkinson, A.M.; Agarwal, R. Silibinin prevents lung tumorigenesis in wild-type but not in iNOS- / - mice: Potential of real-time micro-CT in lung cancer chemoprevention studies. Clin. Cancer Res. 2011, 17, 753-761. [CrossRef]

38. Tyagi, A.; Agarwal, C.; Dwyer-Nield, L.D.; Singh, R.P.; Malkinson, A.M.; Agarwal, R. Silibinin modulates TNF-alpha and IFN-gamma mediated signaling to regulate COX2 and iNOS expression in tumorigenic mouse lung epithelial LM2 cells. Mol. Carcinog. 2012, 51, 832-842. [CrossRef] [PubMed]

39. Bosch-Barrera, J.; Menendez, J.A. Silibinin and STAT3: A natural way of targeting transcription factors for cancer therapy. Cancer Treat. Rev. 2015, 41, 540-546. [CrossRef] [PubMed]

40. Bosch-Barrera, J.; Queralt, B.; Menendez, J.A. Targeting STAT3 with silibinin to improve cancer therapeutics. Cancer Treat. Rev. 2017, 58, 61-69. [CrossRef] [PubMed]

41. Mateen, S.; Tyagi, A.; Agarwal, C.; Singh, R.P.; Agarwal, R. Silibinin inhibits human nonsmall cell lung cancer cell growth through cell-cycle arrest by modulating expression and function of key cell-cycle regulators. Mol. Carcinog. 2010, 49, 247-258. [CrossRef]

42. Mateen, S.; Raina, K.; Jain, A.K.; Agarwal, C.; Chan, D.; Agarwal, R. Epigenetic modifications and p21-cyclin B1 nexus in anticancer effect of histone deacetylase inhibitors in combination with silibinin on non-small cell lung cancer cells. Epigenetics 2012, 7, 1161-1172. [CrossRef]

43. Corominas-Faja, B.; Oliveras-Ferraros, C.; Cuyàs, E.; Segura-Carretero, A.; Joven, J.; Martin-Castillo, B.; Barrajón-Catalán, E.; Micol, V.; Bosch-Barrera, J.; Menendez, J.A. Stem cell-like ALDH(bright) cellular states in EGFR-mutant non-small cell lung cancer: A novel mechanism of acquired resistance to erlotinib targetable with the natural polyphenol silibinin. Cell Cycle 2013, 12, 3390-3404. [CrossRef] [PubMed]

44. Cuyàs, E.; Pérez-Sánchez, A.; Micol, V.; Menendez, J.A.; Bosch-Barrera, J. STAT3-targeted treatment with silibinin overcomes the acquired resistance to crizotinib in ALK-rearranged lung cancer. Cell Cycle 2016, 15, 3413-3418. [CrossRef] 
45. Liang, Z.; Yang, Y.; Wang, H.; Yi, W.; Yan, X.; Yan, J.; Li, Y.; Feng, Y.; Yu, S.; Yang, J.; et al. Inhibition of SIRT1 signaling sensitizes the antitumor activity of silybin against human lung adenocarcinoma cells in vitro and in vivo. Mol. Cancer Ther. 2014, 13, 1860-1872. [CrossRef]

46. Rho, J.K.; Choi, Y.J.; Jeon, B.S.; Choi, S.J.; Cheon, G.J.; Woo, S.K.; Kim, H.R.; Kim, C.H.; Choi, C.M.; Lee, J.C. Combined treatment with silibinin and epidermal growth factor receptor tyrosine kinase inhibitors overcomes drug resistance caused by T790M mutation. Mol. Cancer Ther. 2010, 9, 3233-3243. [CrossRef] [PubMed]

47. Vazquez-Martin, A.; Cufí, S.; Oliveras-Ferraros, C.; Torres-Garcia, V.Z.; Corominas-Faja, B.; Cuyàs, E.; Bonavia, R.; Visa, J.; Martin-Castillo, B.; Barrajón-Catalán, E.; et al. IGF-1R/epithelial-to-mesenchymal transition (EMT) crosstalk suppresses the erlotinib-sensitizing effect of EGFR exon 19 deletion mutations. Sci. Rep. 2013, 3, 2560. [CrossRef] [PubMed]

48. Cufí, S.; Bonavia, R.; Vazquez-Martin, A.; Corominas-Faja, B.; Oliveras-Ferraros, C.; Cuyàs, E.; Martin-Castillo, B.; BarrajónCatalán, E.; Visa, J.; Segura-Carretero, A.; et al. Silibinin meglumine, a water-soluble form of milk thistle silymarin, is an orally active anti-cancer agent that impedes the epithelial-to-mesenchymal transition (EMT) in EGFR-mutant non-small-cell lung carcinoma cells. Food Chem. Toxicol. 2013, 60, 360-368.

49. Cufí, S.; Bonavia, R.; Vazquez-Martin, A.; Oliveras-Ferraros, C.; Corominas-Faja, B.; Cuyàs, E.; Martin-Castillo, B.; BarrajónCatalán, E.; Visa, J.; Segura-Carretero, A.; et al. Silibinin suppresses EMT-driven erlotinib resistance by reversing the high miR-21/low miR-200c signature in vivo. Sci. Rep. 2013, 3, 2459. [CrossRef]

50. Shien, K.; Toyooka, S.; Yamamoto, H.; Soh, J.; Jida, M.; Thu, K.L.; Hashida, S.; Maki, Y.; Ichihara, E.; Asano, H.; et al. Acquired resistance to EGFR inhibitors is associated with a manifestation of stem cell-like properties in cancer cells. Cancer Res. 2013, 73, 3051-3061. [CrossRef]

51. Maitrejean, M.; Comte, G.; Barron, D.; El Kirat, K.; Conseil, G.; Di Pietro, A. The flavanolignan silybin and its hemisynthetic derivatives, a novel series of potential modulators of P-glycoprotein. Bioorg. Med. Chem. Lett. 2000, 10, 157-160. [CrossRef]

52. Dzubák, P.; Hajdúch, M.; Gazák, R.; Svobodová, A.; Psotová, J.; Walterová, D.; Sedmera, P.; Kren, V. New derivatives of silybin and 2,3-dehydrosilybin and their cytotoxic and P-glycoprotein modulatory activity. Bioorg. Med. Chem. 2006, 14, 3793-3810. [CrossRef] [PubMed]

53. Sadava, D.; Kane, S.E. Silibinin reverses drug resistance in human small-cell lung carcinoma cells. Cancer Lett. 2013, 339, $102-106$. [CrossRef]

54. Dinic, J.; Podolski-Renic, A.; Stankovic, T.; Bankovic, J.; Pesic, M. New Approaches With Natural Product Drugs for Overcoming Multidrug Resistance in Cancer. Curr. Pharm. Des. 2015, 21, 5589-5604. [CrossRef] [PubMed]

55. Dobiasová, S.; Řehořová, K.; Kučerová, D.; Biedermann, D.; Káňová, K.; Petrásková, L.; Koucká, K.; Václavíková, R.; Valentová, K.; Ruml, T.; et al. Multidrug Resistance Modulation Activity of Silybin Derivatives and Their Anti-inflammatory Potential. Antioxidants 2020, 9, 455. [CrossRef]

56. Lee, C.K.; Choi, J.S. Effects of silibinin, inhibitor of CYP3A4 and P-glycoprotein in vitro, on the pharmacokinetics of paclitaxel after oral and intravenous administration in rats. Pharmacology 2010, 85, 350-356. [CrossRef] [PubMed]

57. Chu, S.C.; Chiou, H.L.; Chen, P.N.; Yang, S.F.; Hsieh, Y.S. Silibinin inhibits the invasion of human lung cancer cells via decreased productions of urokinase-plasminogen activator and matrix metalloproteinase-2. Mol. Carcinog. 2004, 40, 143-149. [CrossRef]

58. Chen, P.N.; Hsieh, Y.S.; Chiou, H.L.; Chu, S.C. Silibinin inhibits cell invasion through inactivation of both PI3K-Akt and MAPK signaling pathways. Chem. Biol. Interact. 2005, 156, 141-150. [CrossRef]

59. Chen, P.-N.; Hsieh, Y.-S.; Chiang, C.-L.; Chiou, H.-L.; Yang, S.-F.; Chu, S.-C. Silibinin inhibits invasion of oral cancer cells by suppressing the MAPK pathway. J. Dent. Res. 2006, 85, 220-225. [CrossRef]

60. Byun, H.J.; Darvin, P.; Kang, D.Y.; Sp, N.; Joung, Y.H.; Park, J.H.; Kim, S.J.; Yang, Y.M. Silibinin downregulates MMP2 expression via Jak2/STAT3 pathway and inhibits the migration and invasive potential in MDA-MB-231 cells. Oncol. Rep. 2017, 37, 3270-3278. [CrossRef]

61. Davis, F.M.; Stewart, T.A.; Thompson, E.W.; Monteith, G.R. Targeting EMT in cancer: Opportunities for pharmacological intervention. Trends Pharmacol. Sci. 2014, 35, 479-488. [CrossRef]

62. Marcucci, F.; Stassi, G.; De Maria, R. Epithelial-mesenchymal transition: A new target in anticancer drug discovery. Nat. Rev. Drug Discov. 2016, 15, 311-325. [CrossRef]

63. Shibue, T.; Weinberg, R.A. EMT, CSCs, and drug resistance: The mechanistic link and clinical implications. Nat. Rev. Clin. Oncol. 2017, 14, 611-629. [CrossRef]

64. Frederick, B.A.; Helfrich, B.A.; Coldren, C.D.; Zheng, D.; Chan, D.; Bunn, P.A., Jr.; Raben, D. Epithelial to mesenchymal transition predicts gefitinib resistance in cell lines of head and neck squamous cell carcinoma and non-small cell lung carcinoma. Mol. Cancer Ther. 2007, 6, 1683-1691. [CrossRef] [PubMed]

65. Byers, L.A.; Diao, L.; Wang, J.; Saintigny, P.; Girard, L.; Peyton, M.; Shen, L.; Fan, Y.; Giri, U.; Tumula, P.K.; et al. An epithelialmesenchymal transition gene signature predicts resistance to EGFR and PI3K inhibitors and identifies Axl as a therapeutic target for overcoming EGFR inhibitor resistance. Clin. Cancer Res. 2013, 19, 279-290. [CrossRef]

66. Guo, F.; Liu, X.; Qing, Q.; Sang, Y.; Feng, C.; Li, X.; Jiang, L.; Su, P.; Wang, Y. EML4-ALK induces epithelial-mesenchymal transition consistent with cancer stem cell properties in H1299 non-small cell lung cancer cells. Biochem. Biophys. Res. Commun. 2015, 459, 398-404. [CrossRef] [PubMed]

67. Kim, H.R.; Kim, W.S.; Choi, Y.J.; Choi, C.M.; Rho, J.K.; Lee, J.C. Epithelial-mesenchymal transition leads to crizotinib resistance in H2228 lung cancer cells with EML4-ALK translocation. Mol. Oncol. 2013, 7, 1093-1102. [CrossRef] [PubMed] 
68. Gower, A.; Hsu, W.H.; Hsu, S.T.; Wang, Y.; Giaccone, G. EMT is associated with, but does not drive resistance to ALK inhibitors among EML4-ALK non-small cell lung cancer. Mol. Oncol. 2016, 10, 601-609. [CrossRef]

69. Kogita, A.; Togashi, Y.; Hayashi, H.; Sogabe, S.; Terashima, M.; De Velasco, M.A.; Sakai, K.; Fujita, Y.; Tomida, S.; Takeyama, Y.; et al. Hypoxia induces resistance to ALK inhibitors in the $\mathrm{H} 3122$ non-small cell lung cancer cell line with an ALK rearrangement via epithelial-mesenchymal transition. Int. J. Oncol. 2014, 45, 1430-1436. [CrossRef]

70. Nakamichi, S.; Seike, M.; Miyanaga, A.; Chiba, M.; Zou, F.; Takahashi, A.; Ishikawa, A.; Kunugi, S.; Noro, R.; Kubota, K.; et al. Overcoming drug-tolerant cancer cell subpopulations showing AXL activation and epithelial-mesenchymal transition is critical in conquering ALK-positive lung cancer. Oncotarget 2018, 9, 27242-27255. [CrossRef]

71. Debruyne, D.N.; Bhatnagar, N.; Sharma, B.; Luther, W.; Moore, N.F.; Cheung, N.K.; Gray, N.S.; George, R.E. ALK inhibitor resistance in $\mathrm{ALK}(\mathrm{F} 1174 \mathrm{~L})$-driven neuroblastoma is associated with AXL activation and induction of EMT. Oncogene 2016, 35, 3681-3689. [CrossRef] [PubMed]

72. Wei, J.; van der Wekken, A.J.; Saber, A.; Terpstra, M.M.; Schuuring, E.; Timens, W.; Hiltermann, T.J.N.; Groen, H.J.M.; van den Berg, A.; Kok, K. Mutations in EMT-Related Genes in ALK Positive Crizotinib Resistant Non-Small Cell Lung Cancers. Cancers 2018, 10, 10. [CrossRef] [PubMed]

73. Sekar, D.; Krishnan, R.; Panagal, M.; Sivakumar, P.; Gopinath, V.; Basam, V. Deciphering the role of microRNA 21 in cancer stem cells (CSCs). Genes Dis. 2016, 3, 277-281. [CrossRef] [PubMed]

74. Khan, A.Q.; Ahmed, E.I.; Elareer, N.R.; Junejo, K.; Steinhoff, M.; Uddin, S. Role of miRNA-Regulated Cancer Stem Cells in the Pathogenesis of Human Malignancies. Cells 2019, 8, 840. [CrossRef] [PubMed]

75. Lim, Y.Y.; Wright, J.A.; Attema, J.L.; Gregory, P.A.; Bert, A.G.; Smith, E.; Thomas, D.; Lopez, A.F.; Drew, P.A.; Khew-Goodall, Y.; et al. Epigenetic modulation of the miR-200 family is associated with transition to a breast cancer stem-cell-like state. J. Cell Sci. 2013, 126, 2256-2266. [CrossRef]

76. Burk, U.; Schubert, J.; Wellner, U.; Schmalhofer, O.; Vincan, E.; Spaderna, S.; Brabletz, T. A reciprocal repression between ZEB1 and members of the miR-200 family promotes EMT and invasion in cancer cells. EMBO Rep. 2008, 9, 582-589. [CrossRef]

77. Wellner, U.; Schubert, J.; Burk, U.C.; Schmalhofer, O.; Zhu, F.; Sonntag, A.; Waldvogel, B.; Vannier, C.; Darling, D.; zur Hausen, A.; et al. The EMT-activator ZEB1 promotes tumorigenicity by repressing stemness-inhibiting microRNAs. Nat. Cell Biol. 2009, 11, 1487-1495. [CrossRef] [PubMed]

78. Mateen, S.; Raina, K.; Agarwal, C.; Chan, D.; Agarwal, R. Silibinin synergizes with histone deacetylase and DNA methyltransferase inhibitors in upregulating E-cadherin expression together with inhibition of migration and invasion of human non-small cell lung cancer cells. J. Pharmacol. Exp. Ther. 2013, 345, 206-214. [CrossRef]

79. Xu, S.; Zhang, H.; Wang, A.; Ma, Y.; Gan, Y.; Li, G. Silibinin suppresses epithelial-mesenchymal transition in human non-small cell lung cancer cells by restraining RHBDD1. Cell Mol. Biol. Lett. 2020, 25, 36. [CrossRef]

80. Erler, J.T.; Bennewith, K.L.; Nicolau, M.; Dornhöfer, N.; Kong, C.; Le, Q.T.; Chi, J.T.; Jeffrey, S.S.; Giaccia, A.J. Lysyl oxidase is essential for hypoxia-induced metastasis. Nature 2006, 440, 1222-1226. [CrossRef] [PubMed]

81. Barker, H.E.; Cox, T.R.; Erler, J.T. The rationale for targeting the LOX family in cancer. Nat. Rev. Cancer 2012, 12, 540-552. [CrossRef] [PubMed]

82. Cox, T.R.; Gartland, A.; Erler, J.T. Lysyl Oxidase, a Targetable Secreted Molecule Involved in Cancer Metastasis. Cancer Res. 2016, 76, 188-192. [CrossRef] [PubMed]

83. Johnston, K.A.; Lopez, K.M. Lysyl oxidase in cancer inhibition and metastasis. Cancer Lett. 2018, 417, 174-181. [CrossRef]

84. Hou, X.; Du, H.; Quan, X.; Shi, L.; Zhang, Q.; Wu, Y.; Liu, Y.; Xiao, J.; Li, Y.; Lu, L.; et al. Silibinin Inhibits NSCLC Metastasis by Targeting the EGFR/LOX Pathway. Front. Pharmacol. 2018, 9, 21. [CrossRef]

85. Kaipa, J.M.; Starkuviene, V.; Erfle, H.; Eils, R.; Gladilin, E. Transcriptome profiling reveals Silibinin dose-dependent response network in non-small lung cancer cells. PeerJ 2020, 8, e10373. [CrossRef]

86. Pérez-Sánchez, A.; Cuyàs, E.; Ruiz-Torres, V.; Agulló-Chazarra, L.; Verdura, S.; González-Álvarez, I.; Bermejo, M.; Joven, J.; Micol, V.; Bosch-Barrera, J.; et al. Intestinal Permeability Study of Clinically Relevant Formulations of Silibinin in Caco-2 Cell Monolayers. Int. J. Mol. Sci. 2019, 20, 1606. [CrossRef]

87. Bosch-Barrera, J.; Sais, E.; Cañete, N.; Marruecos, J.; Cuyàs, E.; Izquierdo, A.; Porta, R.; Haro, M.; Brunet, J.; Pedraza, S.; et al. Response of brain metastasis from lung cancer patients to an oral nutraceutical product containing silibinin. Oncotarget 2016, 7, 32006-32014. [CrossRef]

88. Priego, N.; Zhu, L.; Monteiro, C.; Mulders, M.; Wasilewski, D.; Bindeman, W.; Doglio, L.; Martínez, L.; Martínez-Saez, E.; Ramón, Y.; et al. STAT3 labels a subpopulation of reactive astrocytes required for brain metastasis. Nat. Med. 2018, 24, 1024-1035. [CrossRef]

89. Sarmiento Soto, M.; Larkin, J.R.; Martin, C.; Khrapitchev, A.A.; Maczka, M.; Economopoulos, V.; Scott, H.; Escartin, C.; Bonvento, G.; Serres, S.; et al. STAT3-Mediated Astrocyte Reactivity Associated with Brain Metastasis Contributes to Neurovascular Dysfunction. Cancer Res. 2020, 80, 5642-5655. [CrossRef] [PubMed]

90. Verdura, S.; Cuyàs, E.; Llorach-Parés, L.; Pérez-Sánchez, A.; Micol, V.; Nonell-Canals, A.; Joven, J.; Valiente, M.; Sánchez-Martínez, M.; Bosch-Barrera, J.; et al. Silibinin is a direct inhibitor of STAT3. Food Chem. Toxicol. 2018, 116, 161-172. [CrossRef] [PubMed]

91. Bromberg, J.F.; Wrzeszczynska, M.H.; Devgan, G.; Zhao, Y.; Pestell, R.G.; Albanese, C.; Darnell, J.E., Jr. Stat3 as an oncogene. Cell 1999, 98, 295-303. [CrossRef] 
92. Liddle, F.J.; Alvarez, J.V.; Poli, V.; Frank, D.A. Tyrosine phosphorylation is required for functional activation of disulfide-containing constitutively active STAT mutants. Biochemistry 2006, 45, 5599-5605. [CrossRef] [PubMed]

93. Shukla, S.K.; Dasgupta, A.; Mehla, K.; Gunda, V.; Vernucci, E.; Souchek, J.; Goode, G.; King, R.; Mishra, A.; Rai, I.; et al. Silibinin-mediated metabolic reprogramming attenuates pancreatic cancer-induced cachexia and tumor growth. Oncotarget 2015, 6, 41146-41161. [CrossRef]

94. Singh, M.; Garg, N.; Venugopal, C.; Hallett, R.; Tokar, T.; McFarlane, N.; Mahendram, S.; Bakhshinyan, D.; Manoranjan, B.; Vora, P.; et al. STAT3 pathway regulates lung-derived brain metastasis initiating cell capacity through miR-21 activation. Oncotarget 2015, 6, 27461-27477. [CrossRef] [PubMed]

95. Thomas, S.; Fisher, K.H.; Snowden, J.A.; Danson, S.J.; Brown, S.; Zeidler, M.P. Methotrexate Is a JAK/STAT Pathway Inhibitor. PLoS ONE 2015, 10, e0130078. [CrossRef]

96. Miklossy, G.; Hilliard, T.S.; Turkson, J. Therapeutic modulators of STAT signalling for human diseases. Nat. Rev. Drug Discov. 2013, 12, 611-629. [CrossRef] [PubMed]

97. Shakibaei, M.; Harikumar, K.B.; Aggarwal, B.B. Resveratrol addiction: To die or not to die. Mol. Nutr. Food Res. 2009, 53, 115-128. [CrossRef]

98. Li, T.; Wang, W.; Chen, H.; Li, T.; Ye, L. Evaluation of anti-leukemia effect of resveratrol by modulating STAT3 signaling. Int. Immunopharmacol. 2010, 10, 18-25. [CrossRef]

99. Liu, L.J.; Leung, K.H.; Chan, D.S.; Wang, Y.T.; Ma, D.L.; Leung, C.H. Identification of a natural product-like STAT3 dimerization inhibitor by structure-based virtual screening. Cell Death Dis. 2014, 5, e1293. [CrossRef]

100. Szelag, M.; Sikorski, K.; Czerwoniec, A.; Szatkowska, K.; Wesoly, J.; Bluyssen, H.A. In silico simulations of STAT1 and STAT3 inhibitors predict SH2 domain cross-binding specificity. Eur. J. Pharmacol. 2013, 720, 38-48. [CrossRef]

101. Tuli, H.S.; Mittal, S.; Aggarwal, D.; Parashar, G.; Parashar, N.C.; Upadhyay, S.K.; Barwal, T.S.; Jain, A.; Kaur, G.; Savla, R.; et al. Path of Silibinin from diet to medicine: A dietary polyphenolic flavonoid having potential anti-cancer therapeutic significance. In Seminars in Cancer Biology; Academic Press: Cambridge, MA, USA, 2020.

102. Liakopoulou, C.; Kazazis, C.; Vallianou, N.G. Silimarin and Cancer. Anticancer Agents Med. Chem. 2018, 18, 1970-1974. [CrossRef] [PubMed]

103. Delmas, D.; Xiao, J.; Vejux, A.; Aires, V. Silymarin and Cancer: A Dual Strategy in Both in Chemoprevention and Chemosensitivity. Molecules 2020, 25, 2009. [CrossRef] [PubMed]

104. Kim, J.; Lee, H.M.; Cai, F.; Ko, B.; Yang, C.; Lieu, E.L.; Muhammad, N.; Rhyne, S.; Li, K.; Haloul, M.; et al. The hexosamine biosynthesis pathway is a targetable liability in KRAS/LKB1 mutant lung cancer. Nat. Metab. 2020, 2, 1401-1412. [CrossRef] [PubMed] 